\title{
Sobre a RotinizaÇão da Sociologia No Brasil: os Primeiros Manuais DidÁticos, SEUS Autores, SUAS EXPECTATIVAS
}

\author{
Simone Meucci ${ }^{1}$
}

\begin{abstract}
RESUMO
Este texto traz alguns dados sobre os primeiros manuais didáticos de sociologia elaborados no Brasil particularmente no período compreendido entre os anos de 1930 e 1945, quando houve uma produção notável destes livros. Analisamos as condições institucionais e editoriais que permitiram a formação deste conjunto de obras, procuramos identificar a origem intelectual de seus autores e as expectativas de que a disciplina era depositária. Constatamos que o estudo dos livros didáticos permite compreender o sentido que fora dado a sociologia no ensino secundário exatamente no período em que se mobilizavam esforços para a institucionalização acadêmica do conhecimento sociológico no país. Esta análise pretende, pois, contribuir para uma abordagem sociológica do processo de constituição da sociologia no Brasil.

Palavras-chave: Sociologia no Brasil. Manuais didáticos. Ensino da sociologia.
\end{abstract}

\begin{abstract}
This text brings selected data about the first didactic sociology manuals elaborated in Brasil, mainly foucusing on the period between 1930 and 1945 during which a great deal of these publications was issued.We analised the institutional and editorial conditions that made it possible for such body of work to be published.We also tried to identify the intellectual origin of the authors and the expectations that were created concerning this subject. We concluded that the study of didactical books enables us to understand the meaning of sociology in the secondary education,which coincided with the period of intense effort of academic institutionalization sociological knowledge in country. This text is an analisys that indends to contribute to a sociological approach of the constitutionalization of the sociology in Brasil.

Key words: Sociology in Brasil. Didactic manuals. Teaching sociology.
\end{abstract}

${ }^{1}$ Doutora em Sociologia pela Universidade Estadual de Campinas (2006). Docente do Centro Universitário Positivo. 


\section{Os Livros Didáticos}

$\mathrm{N}$ Brasil, a publicação de um conjunto significativo de obras introdutórias ao conhecimento sociológico ocorreu repentinamente na década de 30. No período compreendido entre os anos de 1931 e 1945 surgiram mais de duas dezenas de livros dedicados ao ensino da disciplina ${ }^{2}$, ao passo que nas décadas anteriores foram publicados apenas alguns compêndios de sociologia criminal e o conhecido Introdução à Sociologia, de 1926 de Pontes de Miranda (Quadro 1).

A composição repentina de um conjunto notável de livros didáticos da disciplina esteve certamente vinculada a uma série de iniciativas dedicadas à institucionalização da sociologia nos anos 30 que podem ser assim enumeradas:

1. Introdução da cadeira de sociologia nos cursos secundários chamados 'complementares' (1925) e nas Escolas Normais de Pernambuco (1928), Rio de Janeiro (1928) e São Paulo (1933). ${ }^{3}$

2. Criação dos cursos de Ciências Sociais na Escola Livre de Sociologia e Política (1933) (LIMONGI, 1989, 1987), na Universidade de São Paulo (1933) (CARDOSO, 1982), na Universidade do Distrito Federal (1935) (ALMEIDA, 1989; BARBOSA, 1996; VICENZI, 1986), e na Faculdade de Filosofia, Ciências e Letras do Paraná (1938) (TOMAZI, 2006; BEGA, 2006).

3. Publicação das consagradas obras Evolução Politica do Brasil (Caio Prado Júnior, 1933), Casa Grande \& Senzala (Gilberto Freyre, 1933) e Raízes do Brasil (Sérgio Buarque de Holanda, 1936).

4. Surgimento de dicionários, coletâneas de textos e periódicos que, juntamente com os manuais didáticos, se constituíram como os primeiros veículos de difusão do conhecimento sociológico, entre eles o Dicionário de etnologia e Sociologia (1939) de Herbert Baldus e Emílio Willems; o Dicionário de

\footnotetext{
${ }^{2}$ Alguns dos manuais didáticos publicados na década de 30 tornaram-se verdadeiros clássicos do ensino da sociologia no meio intelectual brasileiro: foram reeditados várias vezes e, em muitos casos, por várias décadas. Lições de Sociologia de Achiles Archero Júnior, publicado pela primeira vez em 1932, chegou à nona edição em 1949; Princípios de Sociologia de Fernando de Azevedo, reeditado onze vezes entre 1935 e 1973; Programa de Sociologia de Amaral Fontoura, reeditado quatro vezes no período de 1940 e 1944 (e, sob o novo título Introdução à Sociologia foi ainda reeditado cinco vezes entre 1948 e 1970); Fundamentos de Sociologia de Carneiro Leão reeditado cinco vezes entre 1940 e 1963 e, finalmente, Sociologia de Gilberto Freyre, reeditado também cinco vezes entre 1945 e 1973. 0 sucesso editorial destas obras coloca seus autores entre os mais notáveis divulgadores da Sociologia no sistema escolar e acadêmico brasileiros. E evidencia a consolidação de um modo de difusão do conhecimento sociológico surgido repentinamente nos anos 30 que, não obstante, percorreu incólume longas décadas.

${ }^{3}$ Sobre o ensino da sociologia no sistema escolar brasileiro ver: (MORAES, 2003; PEREZ, 2002; MEUCCI, 2006, 2005).
} 
Sociologia (1939) de Achiles Archero Júnior e Alberto Conte; a revistaSociologia (1939), primeiro periódico especializado em Sociologia publicado por Romano Barreto e Emílio Willems; e a coletânea Leituras Sociológicas (1940), organizada por Romano Barreto e composta por traduções de artigos publicados originalmente na Europa e nos Estados Unidos, traduzidos e reduzidos ao que se considerava essencial para o conhecimento da teoria social entre nós.

Estes tópicos representam sinteticamente o complexo de esforços dedicados à formação dos primeiros portadores do conhecimento sociológico, à consagração das questões, obras e autores fundamentais para a disciplina nova e à formação de uma dinâmica de produção e divulgação das pesquisas e teorias sociológicas no Brasil. Evidentemente o aparecimento dos manuais de sociologia fazia parte deste fenômeno de mobilização para a rotinização do conhecimento sociológico no Brasil. ${ }^{4}$

Não obstante, o surgimento do primeiro conjunto de livros didáticos de sociologia esteve particularmente relacionado a duas condições favoráveis: (a) a consolidação da disciplina no sistema de ensino regular, (b) o surgimento de um mercado editorial especialmente voltado à reprodução de obras sobre o Brasil e ao investimento na área pedagógica.

\section{O Ensino da Sociologia no Brasil: Breve Histórico}

A primeira vez que o conhecimento sociológico ingressou formalmente no sistema de ensino brasileiro foi em 1891, após a reforma educacional protagonizada por Benjamin Constant: chamava-se Sociologia e Moral a nova disciplina obrigatória, cursada pelos alunos dos $6^{\circ}$ e $7^{\circ}$ anos dos cursos secundários. Não obstante, sem que houvessem resistências, foi pouco depois retirada do currículo pela lei que aprovou o regulamento do Ginásio Nacional (atual Colégio D. Pedro II no Rio de Janeiro).

0 reaparecimento da sociologia no sistema de ensino ocorreu apenas no século seguinte em duas circunstâncias. Na primeira delas, em 1925, a partir da Reforma Rocha Vaz, surgiu a exigência de que candidatos às vagas nas faculdades brasileiras dominassem o conteúdo da matéria sociológica: a sociologia passou a ser, pois, conhecimento avaliado nas provas vestibulares. Tal exigência fez com que, em 1926 e 1929, a sociologia aparecesse na grade de disciplinas de nível secundário do Colégio Pedro II, instituição cujos programas e currículos eram modelares para os demais colégios secundários públicos ou privados do

\footnotetext{
${ }^{4} 0$ emprego do termo rotinização compreende o fenômeno de formaçãa de uma comunidade científica e de um quadro institucional a partir do qual é possível uma nova ciência ser produzida sobre bases duráveis. (WEBER, 1994, p.162).
} 
país. (VECHIA; LORENZ, 1998). Em 1931, com a centralização do sistema educacional brasileiro e a reforma de ensino nacional, a sociologia passou finalmente a compor o quadro de matérias dos chamados cursos complementares, que constituíam um período adicional de preparação dos estudantes para 0 ingresso nas faculdades e universidades.

A segunda circunstância que permitiu o reingresso da sociologia ao sistema escolar brasileiro foi também na segunda metade da década de 20, quando a disciplina tornouse presença significativa no currículo dedicado à formação dos educadores primários e secundários em dois importantes estados brasileiros. Ao longo do ano de 1928, os projetos de reforma educacional elaborados nos Estados do Rio de Janeiro e Pernambuco previram a a nova disciplina nos programas de ensino das Escolas Normais.

Este itinerário da disciplina sociológica no sistema escolar brasileiro, aqui apenas esboçado, demonstra que em pouco menos de seis anos - entre o final dos anos 20 e 0 início da década de 30 - a sociologia passou a ser compreendida como uma disciplina necessária para a formação geral de candidatos a bacharéis e professores.

Pouco depois, foi ainda reconhecida como uma disciplina acadêmica: a inauguração dos cursos de graduação em Ciências Sociais na Escola Livre de Sociologia e Política (1933), na Universidade de São Paulo (1934), na Universidade do Distrito Federal (1935) e na Faculdade de Filosofia, Ciências e Letras do Paraná (1938) é manifestação cabal do status ocupado pela matéria sociológica em nosso meio intelectual.

Analisando este percurso da disciplina no sistema de ensino brasileiro, verificamos que, após a permanência inexpressiva no curso médio no último decênio do século XIX, a sociologia ressurgiu cerca de quatro décadas depois, nos currículos dos cursos secundários e acadêmicos: é quando, de fato, após uma longa e irregular trajetória, a disciplina ocupou um lócus institucional notável que tornou possível a inauguração do esforço sistemático de produção e a reprodução do conhecimento sociológico.

É curioso notar como, no Brasil, o ingresso da sociologia nas escolas de nível secundário precedeu a sua introdução na Universidade. Tal fenômeno certamente teve implicações que não foram ainda avaliadas nos estudos sobre a institucionalização da sociologia no Brasil. Exploraremos um pouco dos efeitos desta precedência nos manuais de sociologia produzidos nos anos 30. Rigorosamente, estes livros didáticos foram elaborados sem que houvessem ainda portadores especializados no conhecimento sociológico. Os compêndios elaborados nos anos 30 nos revelam, afinal, as condições - de certo modo dramáticas - de sistematização de uma ciência nova. Nesse sentido, estes livros nos apresentam uma face importante do processo de consolidação do campo sociológico entre nós, ao permitir, a um só tempo, o reconhecimento dos primeiros agentes 
sistematizadores e a identificação de suas expectativas em relação à contribuição da nova disciplina (desde as mais sofisticadas até as mais vulgares) que estiveram na origem dos esforços para a rotinização da sociologia no Brasil.

Convém também a chamar a atenção para o fato de que no ano de 1942, na vigência da Reforma Capanema, a sociologia desapareceu do currículo dos cursos complementares. Foi então mantida apenas na grade curricular dos Cursos Normais, sob a rubrica de Sociologia Geral e/ou Sociologia da Educação.

A exclusão da disciplina na formação geral dos estudantes de nível secundário resultou num debate intenso que envolveu os primeiros cientistas especializados na área que então se tornavam notórios, entre os quais Florestan Fernandes (1955), Costa Pinto (1949) e Antonio Candido (1949).

A rigor, segundo nossas observações, o desaparecimento da sociologia dos cursos complementares causou impacto negativo na produção de obras didáticas. Pode-se notar, na relação de manuais que apresentamos ao final deste texto, que após 1942 foram elaborados apenas dois novos compêndios de sociologia que, não obstante, são obras que compõe uma nova 'safra' dedicada especialmente (ainda que não exclusivamente) ao ensino superior. Teoria e Pesquisa em Sociologia de Donald Pierson e Sociologia: uma introdução aos seusprincípios de Gilberto Freyre estavam certamente voltados ao público dos estudantes de graduação em ciências sociais. Representam, nesse sentido, esforços originais de síntese teórica e metodológica de alguns dos mais significativos portadores especializados do conhecimento sociológico, após suas experiências docentes no Brasil. ${ }^{5}$

Acerca da repercussão da exclusão da disciplina do curso complementar e seus efeitos sobre a produção de livros didáticos, convém ainda observar que um dos autores, Afro do Amaral Fontoura, revisou o conteúdo de seus compêndios anteriores para adequálos às novas condições da disciplina no meio escolar brasileiro. Foi assim o surgimento de Introdução à Sociologia (1948) a partir dos conteúdos de Programa de Sociologia (1940).

\section{O INTERESSE DA INDÚSTRIA EDITORIAL}

Favorável à produção regular de manuais de sociologia foi, também, a iniciativa da nascente indústria editorial brasileira. Nos anos 30, os editores brasileiros, para conseguir concentrar recursos no setor e compor um mercado editorial nacional, investiram de modo notável na publicação de obras pedagógicas. Possivelmente, naqueles primeiros anos de estabelecimento do mercado editorial brasileiro, a produção de livros destinados

\footnotetext{
${ }^{5}$ Sobre a experiência do norte-americano Donald Pierson no ensino das ciências sociais e na profissionalização do novo cientista no Brasil ver Vila Nova (1998).
} 
aos cursos obrigatórios do sistema regular de ensino foi compreendida como investimento seguro já que os alunos matriculados certamente os adquiririam. Os livros didáticos se constituíram, desse modo, como um dos grandes filões de lucro das editoras (PONTES, 1989).

Esta iniciativa beneficiou a nacionalização dos livros aplicados ao ensino no Brasil. As principais editoras brasileiras dedicaram, no período de 1938 a 1943, parcelas significativas de suas publicações ao lançamento de obras pedagógicas. Basta conferir a porcentagem correspondente à publicação deste tipo de livros nas grandes editoras do período: Francisco Alves, RJ (65\%), Nacional SP/RJ (26\%), Melhoramentos, SP (28\%), Globo, Porto Alegre (11\%), Irmãos Pongetti RJ (4\%) José Olympio RJ (1,5\%) (PONTES, 1989, p. 568).

Heloísa Pontes denominou o fenômeno de "o boom do livro didático". (PONTES, 1989, p. 568) Tratou-se da explosão repentina de um mercado de compêndios escolares e acadêmicos que mobilizou, num curto intervalo de tempo, iniciativas para a obra de formação da literatura didática nacional. Foi um empreendimento intelectual e industrial que permitiu a rápida substituição das bibliografias estrangeiras por livros nacionais.

Com frequiência, grandes coleções de livros didáticos eram então lançadas. A editora Globo criou uma coleção de manuais denominada Biblioteca de Iniciação Cultural e Profissional, composta por livros de psicologia, direito, psicanálise, pedagogia e até eletrônica.

A editora Nacional, por sua vez, criou, sob a direção de Fernando de Azevedo, a Biblioteca Pedagógica Brasileira, composta por sessenta volumes organizados em 5 sessões: Brasiliana, Atualidades em Pedagogia, Atualidades Científicas, Livros Infantis e Livros Didáticos.

É importante observar que o processo de nacionalização dos livros didáticos no Brasil repercutiu nos mais variados campos de conhecimento e não se referia apenas à sociologia. Nas áreas de matemática, estatística, biologia e física foram também organizados esforços para a constituição de um conjunto de manuais escolares nacionais. Pode-se, porém, afirmar que nas disciplinas como geografia, história e sociologia os esforços foram especialmente cuidadosos: compreendia-se que os conteúdos destas áreas de conhecimento deveriam ser nacionalizados para que fosse possível fazer reconhecer a hidrografia, a topografia, os fatos históricos e os problemas sociais do país. Esta compreensão estava de acordo com as preocupações nacionalistas que ocuparam nossos intelectuais e educadores na década de 30. Antonio Candido, com efeito, afirma que a mobilização dos editores tinha também sua origem na idéia de que a nacionalização de tais livros era uma maneira de torná-los um instrumento vivo de nossa cultura. (PONTES, 2001). 
Na área de sociologia verificamos publicações de grandes editoras como Globo (RS), Melhoramentos (SP), Saraiva (SP) e José Olympio (RJ). Em conjunto, estas editoras publicaram entre 1930 e 1940, cerca de uma dezena de compêndios introdutórios de sociologia.

Pequenas editoras também acreditavam que a produção de livros escolares era uma boa oportunidade de estabelecer-se firmemente no mercado editorial. Elas participaram de modo significativo, do esforço de composição do conjunto de livros didáticos de sociologia.

Com efeito, boa parte dos manuais de sociologia publicada neste período foi editada por pequenas editoras especializadas, gráficas e livrarias, entre as quais a Gráfica Cruzeiro do Sul (SP), Editorial Paulista (SP), Ariel (RJ), Aurora (RJ), Sauer (RJ), Coelho Branco (RJ), Jornal do Comércio (RJ), Livraria João Amêndola (Campinas), Apollo (RJ), Centro D. Vital (RJ).

Nota-se que as editoras responsáveis pelas publicações de sociologia se concentravam na região sudeste, mais especificamente em São Paulo e Rio de Janeiro à exceção da grande editora Globo, localizada em Porto Alegre. Estas cidades se consolidaram então como centros de produção econômica e intelectual do país.

Apenas os primeiros manuais de sociologia, publicados no início do século XIX, dedicados à explicação sociológica do ato criminoso, foram impressos em Recife pela Livraria Contemporânea. Não podemos esquecer que Recife teve nestaépoca (napassagem do século) uma vida intelectual dinâmica que gravitava em torno da famosa Faculdade de Direito. Porém nas décadas de 20 e 30, com a transferência dos centros de produção agrícola do Nordeste para os estados do Sudeste (particularmente Rio de Janeiro e São Paulo, onde se concentrou o capital proveniente da promissora economia cafeeira), houve também uma transferência dos centros de produção cultural. E foi no Sudeste e no Sul que se estabeleceu a nova indústria editorial brasileira capaz de organizar 0 empreendimento de nacionalizar os livros didáticos.

Convém então observar que a introdução da sociologia no sistema amplo de ensino aliada ao interesse da indústria editorial pela publicação de livros didáticos permitiu a constituição de um conjunto notável de manuais de sociologia. Trata-se, tão simplesmente, da constituição dos primeiros veículos que possibilitaram 0 acesso a conhecimentos que, até então, fora apenas possível aos intelectuais que dominavam, sobretudo, a língua francesa.

\section{Os Autores}

Como observamos, no Brasil, a substituição sistemática de compêndios de sociologia estrangeiros por nacionais ocorreu a partir dos anos 30, após a implantação da 
disciplina nos programas dos cursos complementares e normais e a institucionalização acadêmica das ciências sociais. Tal substituição naturalmente exigiu a mobilização repentina de esforços para a composição de um conjunto significativo de obras. Importante, portanto, procurar identificar, em linhas gerais, a origem dos pioneiros sistematizadores do discurso sociológico.

As indagações básicas que orientarão nossa investigação são as seguintes: Qual formação intelectual dos autores dedicados à formação do primeiro acervo de obras didáticas na área? Que funções desempenhavam na sociedade?

Partimos do pressuposto de que a identificação da formação intelectual e do lugar social ocupado pelos autores dos primeiros manuais de sociologia produzidos entre nós permitirá levantar algumas pistas acerca do significado deste esforço de rotinização da disciplina no ambiente intelectual brasileiro nas décadas de 30 e 40 do último século.

De início, chamamos rapidamente a atenção para os autores dos raros manuais de sociologia surgidos no Brasil nas décadas de 10 e 20, em particular, Paulo Egydio de Carvalho e Francisco Pontes de Miranda. ${ }^{6} 0$ primeiro, professor da Faculdade de Direito de São Paulo, autor de livros de sociologia criminal na primeira década do século XX, importante divulgador das idéias de Durkheim (ALVAREZ, 2000). 0 segundo, professor da Faculdade de Direito do Rio de Janeiro, autor da primeira síntese original de sociologia de grande repercussão no meio intelectual brasileiro - Introdução à Sociologia Geral, publicada em $1926{ }^{?}$

Notemos que tanto Paulo Egydio de Carvalho quanto Pontes de Miranda eram juristas, formados em tradicionais Faculdades de Direito no Brasil e que possivelmente, chegaram à sociologia por meio da discussão acerca das determinações sociais do ato criminoso ou pela ressonância da obra de Augusto Comte e de Herbert Spencer nas faculdades de direito.

Lembramos ainda de Numa Pereira do Valle que, em 1928, publicou o livro Sociologia Applicada: trata-se de um autor sobre o qual poucos dados puderam ser levantados (nada encontramos acerca de sua formação intelectual). De todo modo, o pequeno conjunto de livros que publicou sugere que teve também formação jurídica. ${ }^{8}$

Entre os anos de 1931 e 1945, identificamos precisamente a publicação de 28 manuais de sociologia elaborados por 22 diferentes autores (verificar relação de livros e

\footnotetext{
${ }^{6}$ Ver em anexo a relação dos principais autores, ocupações exercidas e obras publicadas.

${ }^{7}$ Francisco Pontes de Miranda pertenceu à mesma turma de Antonio Carneiro Leão na Faculdade de Direito do Recife: ambos formaram-se em 1911. Carneiro Leão, além de autor de um importante manual de sociologia dos anos 40, foi introdutor da cadeira de sociologia na Escola Normal oficial de Pernambuco em 1928, conforme já citamos.

${ }^{8}$ Ver em anexo a relaçã̃o dos principais autores, ocupações exercidas e obras publicadas.
} 
autores ao final do texto). São eles: Alceu Amoroso Lima, Carlos Delgado de Carvalbo, Achiles Archêro Jr., Rodrigues de Merèje, Miranda Reis, Tito Prates da Fonseca, Nelson Omegna, Djacyr Menezes, Francisca Peeters, Fernando de Azevedo, Guilherme Boing, Manuel Carlos, Roberto Tavares Lyra, Paulo Augusto, Sizinio Leite da Rocha, Antonio Carneiro Leão, Afro do Amaral Fontoura, Juvenal Paiva Pereira, Severino Sombra, Alcionilio Buzzi Alves da Silva, Gilberto Freyre e Donald Pierson.

Nesta relação de autores, ainda que fosse significativa a presença de bacharéis em direito, a formaçã̃o acadêmica foi muito mais difusa. Dos 22 autores que compõem esta lista, cinco se formaram nas tradicionais faculdades de ciências jurídicas e sociais. Os demais concluíram seus estudos em áreas diversas como filosofia, economia, diplomacia ou mesmo odontologia e farmácia.

De qualquer maneira, os bacharéis em direito que se dedicaram a elaboração de sínteses didáticas de sociologia a partir dos anos 30 representavam ainda uma parcela significativa. São eles: Alceu Amoroso Lima, Djacir Menezes (ambos concluíram seus cursos na Faculdade de Direito do Rio de Janeiro), Antonio Carneiro Leão, Roberto Tavares Lyra (que freqüentaram a Faculdade de Direito do Recife) e Fernando de Azevedo (que estudou sob as arcadas da Faculdade de Direito de São Paulo). Entre os outros autores verificamos o seguinte: dois com formação em filosofia (Amaral Fontoura e Nelson Omegna), dois formados na área de saúde (Paulo Augusto - pseudônimo de Pedro A. Pinto - e Juvenal Paiva Pereira), um com formação em diplomacia (o francês, filho de brasileiros, Carlos Delgado de Carvalho), um que realizou seus estudos na academia militar (Severino Sombra), um com formação em economia (Tito Prates da Fonseca) e, por fim, dois cuja formação precisa não pudemos identificar, mas que exerciam a atividade religiosa (Madre Francisca Peeters e o Padre Alcionílio Bruzzi Alves da Silva). ${ }^{9}$

Infelizmente, sobre a formação acadêmica de Guilherme Boing, Miranda Reis, Manoel Carlos, Sizínio Leite da Rocha, João Rodrigues Merèje e Achiles Archêro Jr. não conseguimos ainda obter dados.

Apenas dois autores desta lista analisada tiveram formação mais ou menos sistemática em ciências sociais: Donald Pierson, norte-americano que chegou ao Brasil com missão acadêmica na Escola Livre de Sociologia e Política; e Gilberto Freyre, pernambucano que concluiu estudos de graduação e pós-graduação nos Estados Unidos na década de 20 .

Pierson doutorou-se em ciências sociais na Universidade de Chicago, que abrigava,

\footnotetext{
${ }^{9}$ É possível que o Pe. Alcionílio tenha concluído estudos na área jurídica, pois entre suas obras encontramos um livro de introdução à Ciência do Direito.
} 
na época, um dos programas acadêmicos mais importantes do mundo na área. (EUFRÁSI0, 1999; VILANOVA, 1998) Freyre, por sua vez, concluiu curso de graduação em ciências jurídicas e sociais na Universidade de Baylor, localizada na cidade de Waco, interior do Texas, Estados Unidos. Entretanto, não é possível dizer que 0 autor pernambucano teve ali uma formação jurídica no sentido estrito do termo. Os dados levantados por Maria Lucia Pallares-Burke nos mostram que das 22 disciplinas cursadas por Freyre durante a graduação, nove foram oferecidas pelo departamento de língua e literatura, cinco de sociologia, duas de história, duas de zoologia e as restantes de geologia, economia, psicologia, bíblia e ética cristã. Do mesmo modo, quando Freyre freqüentou 0 curso de mestrado em estudos jurídicos e sociais na Universidade de Columbia, em Nova Iorque, das catorze disciplinas nas quais se matriculou, apenas duas referiam-se às questões jurídicas. As demais compreendiam história, sociologia, antropologia, arte, literatura e língua inglesa (PALLARES-BURKE, 2005, p. 62).

Nesse sentido, a julgar pelos estudos feitos por Freyre nos Estados Unidos, épossivel afirmar que 0 autor foi - ao lado do americano Donald Pierson - um dos únicos de nossa lista que tivera acesso a um ambiente acadêmico no qual as ciências sociais foram objeto de reflexão mais ou menos especializada. Certamente não é casual o fato de que ambos - Freyree Pierson - tenham publicado seus compêndios da matéria sociológica exatamente no ano de 1945, pouco após a queda da obrigatoriedade do ensino da disciplina nos cursos de nível médio e a inauguração dos cursos pós-graduados em ciências sociais no Brasil. ${ }^{10}$

Com efeito, conforme já tivemos a oportunidade de observar, os manuais 'Sociologia: uma introdução aos seusprincípios' de Gilberto Freyre e 'Teoria epesquisa em Sociologia' de Donald Pierson marcaram o surgimento de uma nova safra de compêndios de sociologia que atenderam às expectativas de especialização do campo sociológico no meio acadêmico. Em suas páginas, os autores buscaram assinalar, cada qual ao seu modo, a especificidade do objeto e do método da sociologia.

Mas voltemos aos demais autores. 0 que se observa (à exceção de Freyre e Pierson) é que a aprendizagem intelectual dos autores das primeiras sínteses didáticas do conhecimento sociológico surgidas entre nós nos anos 30 - ainda que não ocorresse mais exclusivamente nas Faculdades de Direito - se realizou em condições muito convencionais. De modo geral, senão nas instituições de ensino jurídico, a formação destes autores se realizou sob os cuidados de tradicionais faculdades de ensino de saúde, de instituições militares ou da igreja católica.

Sabe-se, a rigor, que a sociologia tornou-se conhecida entre nós por meio da

\footnotetext{
${ }^{10} 0$ próprio Donald Pierson inaugurou, em 1943, a Divisão de Estudos Pós-Graduados em Ciências Sociais na Escola Livre de Sociologia e Política de São Paulo.
} 
enorme ressonância da obra de Augusto Comte no meio intelectual brasileiro. 0 primeiro interesse da intelectualidade brasileira pela obra de Auguste Comte ocorreu por volta da terceira metade do século XIX. A partir deste período surgiram, sobretudo nas Escolas da Marinha, nas Escola Politécnicas, nas Faculdades de Medicina, e, sobretudo, nas Faculdades de Direito referências ocasionais à nova área de conhecimento fundada pelo filósofo francês (ALONSO, 1996, p. 109-134).

É prudente considerar que, possivelmente, esta repercussão do conhecimento sociológico entre autores de áreas tão diferentes guarda uma relação com a paulatina complexificação do meio acadêmico brasileiro.

Não obstante, a origem mais ou menos heterogênea dos autores aqui referidos torna admissível ponderar a hipótese de que houve, especialmente nos anos 30 - a partir das condições favoráveis dadas pela institucionalização da sociologia no sistema escolar e acadêmico e pela indústria editorial - uma maior mobilização para a composição de um conjunto importante de obras didáticas da disciplina. Uma mobilização de tal ordem que fora capaz de envolver tanto bacharéis em direito, como os bacharéis em farmácia, filosofia ou economia para esta tarefa. Não há, pois, dúvidas de que a grande maioria dos autores pertencia a uma elite intelectual que transitava livremente entre diversas áreas de conhecimento (já que as fronteiras não eram bem determinadas).

Era também relativamente heterogênea a perspectiva teórico-ideológica destes autores Encontramos, pois, entre eles, integralistas, católicos conservadores e reformistas educacionais da Escola Nova. ${ }^{11}$ Porém representam apenas parcialmente 0 gradiente ideológico das disputas políticas do período, pois há a ausência eloqüente de representantes de um grupo importante nos embates da época: os socialistas e comunistas.

Com efeito, observamos, entre os primeiros livros didáticos de sociologia produzidos no Brasil, uma total ausência da perspectiva teórica marxista. Um indicativo de que a disciplina é institucionalizada por certos setores intelectuais que, ainda que por vezes apresentassem perspectiva inovadora e crítica, não assumiam a radicalidade da proposta socialista e comunista.

Sobre a origem social destes autores, sabe-se que alguns provinham de famílias tradicionais do Nordeste (possivelmente de origem oligárquica) que, com alguma frequiência, migravam para o Sudeste (especialmente o Rio de Janeiro) e ali radicavam as

\footnotetext{
${ }^{11} \mathrm{~A}$ Escola Nova foi um movimento no âmbito da educação com ressonância mundial que teve como protagonistas os seguintes educadores: na Europa, Edouard Clapedère (1973-1940), Adolphe Ferrière (1879-1960) e Maria Montessori (1870-1952); nos Estados Unidos, John Dewey (1859-1952). No Brasil, embora o escolanovismo estivesse presente nas reformas educacionais dos anos 20 , só adquiriu contornos de um movimento intelectual sistemático nos anos 30 com a publicação do Manifesto dos Pioneiros da Escola Nova (1932) do qual Fernando de Azevedo e Carneiro Leão foram signatários.
} 
suas atividades intelectuais. É o caso de Carneiro Leão, Severino Sombra, Francisco Pontes de Miranda e Djacir Menezes. ${ }^{12}$

Este itinerário rumo ao Rio de Janeiro era mais ou menos comum entre os bacharéis nordestinos que procuravam na Capital da República (naquele período o grande pólo de atração de editoras, literatos e intelectuais) melhores oportunidades de seguir carreira. ${ }^{13}$ Uma das exceções é o caso do pernambucano Gilberto Freyre que, embora tivesse morado no Rio de Janeiro nas décadas de 30 e 40 (ainda que irregularmente, durante algumas temporadas apenas), retornou definitivamente ao Recife, onde fundou, em 1949, o Instituto Joaquim Nabuco de Pesquisas Sociais (FRESTON, 1989).

Vale à pena destacar que uma parte notável destes autores desempenhou funções políticas. Juvenal Paiva Pereira foi vereador em Itapetininga, interior de São Paulo. Os autores Nelson Omegna, Severino Sombra e Gilberto Freyre foram Deputados Federais. ${ }^{14}$ Nelson Omegna e Roberto Lyra chegaram a ser Ministros de Estado. Por fim, Fernando de Azevedo e Carneiro Leão foram Diretores de Instrução Pública, designação que corresponde, mais ou menos, ao atual cargo de Secretário de Educação dos Estados.

Entre os poucos autores de sínteses sociológicas elaboradas das décadas de 10 e 20 observamos igualmente o exercício da atividade política: Paulo Egydio de Carvalho foi Senador e Pontes de Miranda, Embaixador brasileiro na Colômbia.

Os cargos exercidos parecem atestar que parcela significativa destes autores era originária de uma elite que tinha posse de capital político. Nesse sentido, pode-se dizer que parte considerável dos pioneiros sistematizadores do conhecimento sociológico gravitava em torno do Estado ou era parte integrante dele. ${ }^{15}$

Ao examinar o conjunto das obras publicadas por este conjunto de autores observamos que se dedicavam a temas muito diversificados. Escreviam desde livros acerca daprática da educação física (Fernando de Azevedo) até tratados sobre finanças empresariais (Djacir Menezes). Encontramos ainda, entre seus escritos, dicionários de medicina (Paulo Augusto), sínteses históricas sobre educação (Francisca Peeters) e literatura (Fernando de Azevedo), compêndios de química (Alcionílio B. A. da Silva e Rodrigues Merèje), direito (Alcionílio B. A. da Silva, Rodrigues Merèje, Roberto Lyra), economia (Guilherme Boing), história (Delgado de Carvalho), geografia (Nelson Omegna, Delgado de Carvalho) e serviço social (Amaral Fontoura).

\footnotetext{
${ }^{12}$ Ao cotejar os dados dos autores constatamos uma coincidência: Severino Sombra e Djacir Menezes nasceram ambos no ano de 1907, na cidade de Maranguape (que hoje compõe a região metropolitana de Fortaleza).

${ }^{13}$ Acerca da acomodação de literatos nordestinos no Rio de Janeiro ver: (SORÁ, 1998).

${ }^{14}$ Freyre foi, também, no período compreendido entre os anos de 1926 e 1930, chefe de gabinete de Estácio Coimbra, Governador de Pernambuco, um dos mais importantes oligarcas do período.

${ }^{15}$ Werneck Vianna analisa os dilemas da institucionalização das ciências sociais no Brasil, especialmente a relação ambígua dos intelectuais com o Estado (VIANNA, 1997).
} 
Com efeito, muitos autores dedicaram-se com especial atenção à tarefa de elaboração de manuais. Delgado de Carvalho consagrou-se como um dos mais notáveis divulgadores do conhecimento sociológico durante os anos 30: em menos de uma década publicou cinco consagrados manuais: Sociologia, Sociologia e Educação, Sociologia Educacional, Sociologia Experimental e Práticas de Sociologia. Publicou também compêndios de geografia e história.

Rodrigues de Meréje, Amaral Fontoura e Djacir de Menezes publicaram, além dos manuais de sociologia, também compêndios de psicologia, direito, pedagogia, serviço social, história e geografia. Acabaram por cumprir a função de divulgadores de novas disciplinas científicas no sistema escolar brasileiro.

A produção numerosa e diversificada destes pioneiros é testemunho do baixo índice de especialização das tarefas intelectuais nos anos 30 entre nós. Os autores eram polivalentes sistematizadores de conhecimentos que atenderam à nova demanda de 'nacionalização' dos conteúdos escolares e acadêmicos.

Importante notar a proximidade de alguns destes autores com as editoras. Fernando de Azevedo foi diretor da Editora Nacional. Gilberto Freyre tinha proximidade pessoal com José Olympio e coordenou por alguns anos a coleção Documentos Brasileiros lançada pela editora em 1936. Alceu Amoroso Lima foi um dos fundadores da Agir, editora católica criada em 1944.

Além da proximidade com a indústria editorial, muitos dos autores aqui referidos escreviam em jornais diários. Não se pode esquecer o jornal era, naépoca, o locus central no qual se instauravam polêmicas, divulgavam-se idéias e pessoas. Nesse sentido, crônicas diárias ou semanais acerca de temas variados (como crítica literária, religião, política, etc.) constituíam um mecanismo de consagração indispensável a qualquer sujeito com pretensão de construir uma carreira intelectual (MICELI, 1989, p. 103).

Dentre os dados levantados acerca dos pioneiros escritores de livros didáticos de sociologia um é especialmente significativo. É que além de se ocuparem com tarefas na tribuna pública, no mercado editorial e na imprensa diária, observamos que a grande maioria exerceu atividade docente durante longo período de suas vidas. Estavam, pois, bastante comprometidos com a ação educacional.

E na condição de polivalentes, naturalmente ministravam aulas em disciplinas diversas. As matérias "Doutrina Social", "Serviço Social", "Administração Escolar", "Geografia", "História", "Economia", "Latim", "Psicologia", "Pedagogia" e "Direito criminal" estavam entre o repertório docente de nossos autores.

Alguns não eram propriamente figuras notáveis em nosso meio intelectual. Atuavam como professores quase anonimamente, não fosse a difusão de seus compêndios didáticos. Amaral Fontoura, por exemplo, formou-se em magistério e foi professor nos 
cursos Normais do Rio de Janeiro quando publicou o seu primeiro manual. Alguns anos depois, já formado na Faculdade de Filosofia da Universidade do Brasil, passou a dar aulas de sociologia e serviço social nas principais faculdades fluminenses. Francisca Peeters, por sua vez (única mulher entre nossos autores), era madre, professora de uma escola confessional na cidade de Jaboticabal, interior de São Paulo. Juvenal Paiva Pereira e Rodrigues Merèje lecionaram também em escolas do interior de São Paulo: nas cidades de Itapetininga e Agudos respectivamente. Severino Sombra ministrou aulas de sociologia na Escola Militar do Realengo. Achiles Archero Júnior fora auxiliar de ensino de Fernando de Azevedo no Instituto de Educação da Universidade de São Paulo.

Até mesmo os mais conhecidos autores tiveram significativa experiência docente. Especialmente na disciplina de sociologia encontramos Fernando de Azevedo na Universidade de São Paulo; Gilberto Freyre na Escola Normal de Pernambuco e na Universidade do Distrito Federal; Alceu Amoroso Lima no Centro D. Vital e no Instituto Católico de Estudos Superiores ${ }^{16}$; Delgado de Carvalho na Escola D. Pedro II e no Instituto de Educação do Rio de Janeiro, Antonio Carneiro Leão e Miranda Reis na Universidade do Distrito Federal.

Estes dados nos levam a crer que a maioria dos manuais foi resultado da organização dos conteúdos dos cursos que os autores ministravam. Com efeito, sabemos que o livro Iniciação à Sociologia de Alceu Amoroso Lima foi composto a partir de suas notas de aulas. Antes de ser publicado, este manual (primeira síntese elaborada no Brasil do que se convencionou chamar de sociologia cristã) circulava em páginas datilografadas entre os alunos do Centro D. Vital. Da mesma forma, os manuais "Fundamentos de Sociologia" (de Carneiro Leão) e "Sociologia: introdução aos seus princípios" (de Gilberto Freyre) resultaram da compilação das aulas de sociologia oferecidas por seus autores na Universidade do Distrito Federal. ${ }^{17}$

Porém, em muitos casos, a ação educacional dos autores ultrapassava a atividade docente. Alguns deles trabalharam, ainda nos anos 20, na implantação de projetos de

\footnotetext{
${ }^{16}$ Em 1928, ao assumir a presidência do Centro D. Vital, Alceu de Amoroso Lima quis converter o Centro num núcleo de estudos para a formação de uma cultura católica superior. Para isso, promoveu conferências semanais sobre temas filosóficos, sociológicos, educacionais e religiosos. 0 nascimento do Instituto Católico de Estudos Superiores, fundado em 1932, foi um avanço institucional nesta direção da formação de uma intelectualidade católica. Representou a especialização da tarefa de difundir uma cultura católica superior e a abolição do amadorismo das palestras e cursos até então vigentes no Centro D. Vital. No seu primeiro ano de funcionamento eram três as disciplinas obrigatórias: Sociologia, Filosofia e Teologia. Foi este o germe para a fundação da Universidade Católica (SALEM, 1982)

${ }^{17}$ Sobre os manuscritos de aula de Gilberto Freyre consultar: (MEUCCI, 2006, p. 139). Especificamente sobre a introdução da sociologia no currículo da Escola Normal de Pernambuco pela Reforma Carneiro Leão (MEUCCI, 2005).
} 
reforma de ensino. Carneiro Leão protagonizou, naquela década, uma grande reforma em Pernambuco na qual propôs o ensino da sociologia na Escola Normal do Estado (SELLAR0, 2000). Fernando de Azevedo, por sua vez, foi, nesta mesma época, dirigente das reformas educacionais ocorridas no Distrito Federal e em São Paulo no final dos anos 20 e igualmente propôs a introdução da nova disciplina nos currículos das normalistas.

Importante ainda lembrar que Alceu Amoroso Lima, Djacir Menezes e Severino Sombra fundaram instituições de ensino privadas. Amoroso Lima foi, em 1932, um dos importantes defensores do projeto de criação do Instituto Católico de Estudos Superiores, embrião da Universidade Católica. Djacir de Menezes criou a Faculdade de Economia do Ceará que, na década de 60, foi incorporada à Universidade Federal do Ceará. E Severino Sombra criou uma Universidade privada no interior do Rio de Janeiro, na cidade de Vassouras, hoje denominada Universidade Severino Sombra.

Observamos, portanto, que agnósticos ou católicos, grandes intelectuais preocupados com o destino da nação e com a reformulação do ensino brasileiro, ou mesmo, tão simplesmente, experientes professores, sabemos que os autores aqui referidos assumiram funções relevantes na área educacional. Daí o compromisso estreito com a difusão de material didático novo, com a atividade docente, com as reformas educacionais, com a fundação de novas instituições de ensino superior.

Com efeito, de modo geral, os intelectuais brasileiros deste período acreditavam que a ação educativa era o recurso mais eficaz para a formação de uma nação forte. A centralidade e a importância dada à educação fez com que a natureza da ação educativa fosse, nos anos 30, objeto de um debate severo, protagonizado por dois grupos de intelectuais: os "escolanovistas" que esperavam ampliar a rede escolar pública, reformular programas e eliminar o ensino religioso das obrigações escolares; e os católicos, que tinham como objetivo fundamental, dentro do quadro de reformas que se esboçava, defender o ensino privado e conservar o ensino religioso na rede pública escolar.

Não nos parece casual o fato de encontrarmos, entre os autores dos primeiros compêndios de sociologia, dois dos maiores representantes desta clivagem acerca dos destinos da educação no país: Fernando de Azevedo e Alceu Amoroso Lima. 0 primeiro, conforme já foi mencionado, líder do movimento de reforma de ensino no Rio de Janeiro e em São Paulo, professor de Sociologia na Universidade de São Paulo; o segundo, igualmente apresentado, o maior representante do ideário católico no período, coordenador do Centro D. Vital, da Liga Eleitoral Católica e criador do Instituto Católico de Estudos Superiores onde também ministrou aulas de sociologia.

Com efeito, nas páginas de Iniciação à Sociologia e Princípios de Sociologia (de Fernando de Azevedo e Alceu Amoroso Lima respectivamente), seus autores explicitavam 
e fundamentavam sociologicamente as suas respectivas posições. Isso equivale a dizer que este embate acerca da ação educacional tomou a forma de um confronto pela definição de sociedade: os grupos antagônicos disputavam a legitimidade e o monopólio da explicação sobre a natureza da vida social.

Nesse sentido, nos parece que a sociologia assumiu um papel importante. Desde o final dos anos 20 e principalmente na década de 30, o confronto entre diferentes projetos de nação da elite intelectual brasileira se traduziu sob a forma de confronto entre diferentes perspectivas sociológicas.

Curioso notar que setores importantes e decisivos do meio intelectual e político brasileiro atenderam ao chamado de produção de sínteses sociológicas: dentre eles juristas notáveis, políticos, intelectuais católicos, reformadores educacionais e militares.

Parece-nos, portanto, que a sociologia passou a se constituir como uma linguagem importante do período. Por isso é que, provavelmente, a disciplina foi capaz de mobilizar de modo rápido tantos setores da intelectualidade brasileira e sua institucionalização e rotinização adquiriu contornos tão nítidos. 0 discurso sociológico era então força atuante nos debates da época.

\section{As Expectativas}

Inevitável indagarmos acerca das expectativas que mobilizaram estes autores nesta empreitada de constituição do primeiro conjunto de livros didáticos de sociologia. Decifrar isto é afinal compreender mais profundamente o sentido que o conhecimento sociológico adquiriu para uma geração inteira.

As páginas dos manuais de sociologia nos oferecem algumas pistas interessantes. Os testemunhos dos autores sugerem, sobretudo, que 0 interesse pela sociologia estava relacionado ao que chamaremos aqui de movimento 'realista' no meio intelectual brasileiro. 0 fundamento social deste movimento foi o lento esgarçamento do pacto republicano, pois foi ao longo do desenrolar desta crise (que na segunda metade dos anos 20 adquiriu contornos dramáticos) que os intelectuais, no esforço para compreensão do processo social e político em curso, consagraram a seguinte interpretação: a inoperância do governo diante das dificuldades era, sobretudo, resultante da cisão entre o Estado e a sociedade brasileira. Na expressão de Alberto Torres, havia uma oposição entre o Brasil real e o Brasil legal.

Com efeito, segundo o ponto de vista da inteligência brasileira do período, os pressupostos liberais evocados nas leis que davam ossatura ao Estado brasileiro de então não encontravam correspondência na sociedade que, por sua vez, diante da inoperância 
estrutural do governo, tornava-se dia a dia mais complexa, dotada de nova dinâmica econômica, animada por novos agentes sociais.

Este diagnóstico conduzia de um lado, à desvalorização da prática jurídica e, de outro, acabava por convocar as novas gerações para o conhecimento do que então se convencionou denominar 'realidade brasileira'. Conhecer a realidade social passou então a ser compreendido como um imperativo, quase uma religião cívica, condição necessária para celebração de um novo acordo político capaz de nos conduzir a um melhor destino.

Foi neste período que houve simultaneamente a crítica severa à formação dos juristas e o estímulo à repercussão do conhecimento sociológico. Entendia-se que os bacharéis em direito acumulavam saber literário e enciclopédico, empolgavam-se pela abstração teórica sem estabelecer nexos com o curso da vida social. A sociologia, por sua vez, parece então ter representado uma porta de entrada para uma nova atitude na qual o conhecimento estaria duplamente ligado à realidade: de um lado, a produção do saber sociológico teria a sua origem na observação de fatos concretos, de outro, o conhecimento, assim produzido, resultaria em intervenções eficientemente planejadas e controladas.

A expectativa era de que o conhecimento sociológico - originário da observação empírica - permitisse que a transformação da realidade fosse possível sobre bases concretas e factíveis. Assim se imaginava uma conciliação entre as idéias e os fatos, entre as leis e o processo social, entre Estado e Sociedade. A sociologia era, pois, compreendida como uma novidade na vida intelectual que contrastava com o idealismo imobilista da perspectiva jurídica.

Possivelmente este ambiente de oposição entre o saber jurídico e o saber sociológico impediu que a institucionalização da sociologia se realizasse nas academias de direito. Isso evidentemente exige estudos mais aprofundados, mas parece claro que havia uma animosidade entre as duas áreas neste contexto no qual se evocava o 'realismo sociológico' como um caminho para um futuro mais promissor.

Com efeito, nas páginas dos primeiros manuais de sociologia os autores expressam e positivizam o compromisso da sociologia com a realidade e com a transformação social. 0 suposto realismo e o envolvimento sociológico com o melhoramento da sociedade eram compreendidos muitas vezes em oposição à 'ficção literária', à 'erudição', ao 'diletantismo', ao 'proselitismo'. A sociologia foi então representada como um conhecimento 'exato', 'imparcial', 'aplicável'. São abundantes as passagens nas quais isso se manifesta nos primeiros compêndios didáticos de sociologia.

Amaral Fontoura nos diz que o 'século XX é o século da sociologia, assim como o século XVIII fora o século da literatura'. (FONTOURA, 1953, p. XXIV). Djacir Menezes faz comentário mais incisivo que diz respeito ao mesmo fenômeno. Reivindica o banimento do 'romantismo literário pseudo-sociológico' afirmando que... 
[...] só a ciência, banindo fetichismos e mitos de toda ordem, poderá fornecer a visão clara, nítida, segura de nossa evolução sociológica, dando-nos os meios de avançar em todos os domínios onde se há de expandir a nossa atividade como povo (MENEZES, 1934).

É freqüente nas introduções e apresentações aos livros, o alerta dos autores de que seus compêndios de sociologia não se destinavam à formação de intelectuais eruditos. As primeiras palavras de apresentação do manual 'Noções de Sociologia', de Francisca Peeters, nos previnem: 'este modesto ensaio não aspira foros de erudito'. (PEETERS, 1938). Fernando de Azevedo, igualmente, na introdução ao 'Princípios de sociologia' nos diz que o ensino da disciplina deve ser marcado pelo 'caráter diferencial da formação da formação de um erudito' (AZEVEDO, 1939). Achiles Archero ressalta em 'Lições de Sociologia' que seu manual 'não foi feito para eruditos'. (ARCHERO, 1935, p.11).

Diletantismo, proselitismo e enciclopedismo foram compreendidos como atitudes a serem combatidas. Não se queria, principalmente, ver a sociologia como uma disciplina objeto do exercício intelectual de diletantes. Nelson Omegna, em Elementos de sociologia, preocupa-se com o fato dos 'diletantes' pensarem que a sociologia é uma ciência na qual podem transitar despreocupada e serenamente. (OMEGNA, 1934, p. 24).

Os autores dos livros didáticos de sociologia afirmavam repetidamente a intenção de realizar, nas páginas de seus livros, sínteses adequadas à formaç̧ão de novos espíritos especializados a fim de tornar o conhecimento sociológico mais prestativo e útil (AZEVEDO, 1939). A maioria afirmava que o objetivo era iniciar os alunos na nova área de conhecimento, familiarizá-los com as teorias e técnicas de pesquisa sociológica e, principalmente, despertar o interesse para o novo campo de estudos que estava então para seformar.

Imparcialidade, crítica e nexo com os fatos da realidade são compreendidos como virtudes entre os autores dos manuais. A emissão de opiniões pessoais e a atenção privilegiada a um ponto de vista teórico apenas deveriam ser evitados. Djacir de Menezes em 'Princípios de sociologia' afirma que como não lhe interessa o proselitismo, adotou o critério frio da imparcialidade científica no estudo dos fatos sociais, não adotando nenhum ponto de vista sectário (MENEZES, 1934, p. 7).

Amoroso Lima, na apresentação ao manual 'Programa de Sociologia' de Amaral Fontoura, louva a atitude imparcial do autor: '[...] o autor [Amaral Fontoura] tem 0 cuidado de expor, sempre que o assunto exige, as várias correntes em jogo, sem procurar iludir o leitor pela adoção de uma determinada corrente, como se essa fosse a única verdadeira'. (FONTOURA, 1944, p. 14). 
E por entender que a sociologiaé uma área de conhecimento interessada nos fatos da vida e não apenas nas idéias, os autores dos manuais declaram como um imperativo a necessidade de tornar o ensino da disciplina menos verbal e livresco, procurando estabelecer relações entre as leis sociológicas e a realidade social.

Delgado de Carvalho, em 'Práticas de sociologia', comenta acerca de seu zeloso esforço na fixação de relação entre as idéias sociológicas e os fatos da vida social. Afirma ter procurado em cada um dos temas sociológicos discutidos em seu livro, examinar o ponto de vista brasileiro para ficar patente o interesse nacional que nos prende a estas discussões (CARVALHO, 1933). Nelson Omegna, em 'Elementos de sociologia' nos diz que o que o moveu no seu trabalho de elaboração da síntese didática de sociologia [...] foi o desejo de aplicar as lições à vida de nossa terra (OMEGNA, 1934, p. III). Carneiro Leão igualmente afirma que a sociologia, estudo das origens, da estrutura, das mudanças, do desenvolvimento nas relações sociais, tem de manter-se em contato intimo com a sociedade em que é ministrada ou falta-lhe nexo com o currículo escolar. (CARNEIRO LEÃO, 1940, p. 2).

Por vezes, os autores conclamavam a reunião de esforços para que os alunos mergulhassem na análise da realidade nacional. Achiles Archero, em 'Lições de sociologia', faz o seguinte apelo aos seus alunos: procurem se interessar pelos nossos temas sociológicos, estudem com afinco as questões nacionais, pois estão a exigir de todos uma solução adequada. (ARCHER0, 1935, p. 13).

Alguns autores, como Amaral Fontoura relacionavam o interesse com a realidade a um exercício de brasilidade. Consultemos suas próprias palavras:

0 ensino da sociologia deve e precisa ser um ensino de brasilidade. É comum encontrarmos jovens patrícios na mais completa ignorância dos problemas sociais do país. Nada sabem a respeito de nossas instituições políticas, desconhecem os problemas econômicos de nossa terra, não tem noção dos problemas que afligem nossa sociedade [...] Nem se pretenda pensar que esses assuntos só interessam aos candidatos das Faculdades de Direito. Absolutamente não. Conhecer os problemas sociais da sua pátria é obrigação tanto do advogado como do médico. Estar ao par das instituições do seu país é dever tanto do intelectual quanto do operário, tanto do homem de gabinete quanto do homem de rua! Em suma: conhecer os problemas sociais do Brasil é obra da sociologia e é também dever do patriotismo (FONTOURA, 1944, p. 19).

Observa-se, portanto, que os autores dos manuais compreendiam, apoiados nas recomendações da moderna pedagogia (um campo de conhecimento que então também se afirmava entre nós) e numa perspectiva realista que assumia contornos de obrigação 
cívica que as teorias e conceitos sociológicos deveriam ser apresentados nas suas manifestações mais concretas e evidentes.

Para estimular a descoberta da 'realidade nacional' entre os alunos, os autores sugeriam atividades capazes de despertar o interesse pelas questões sociais, tais como seminários, debates, excursões e pesquisas de campo. Estas atividades eram entendidas como condição para a formação de espíritos críticos, dispostos a refletir, investigar e observar atentamente o fluxo contínuo e intermitente da vida social.

As atividades sugeridas exigiam não apenas do aluno, mas também do professor, um papel ativo. Segundo os autores dos manuais, cabia ao professor a tarefa de disciplinar os alunos, torná-los aptos a consultar bibliografias complementares, auxiliá-los nos desafios dos trabalhos de campo, na aplicação de questionários, na reunião de dados inéditos.

Uma leitura preliminar dos manuais nos permite dizer, entretanto, que, em muitos casos, os longos textos dos manuais, sempre em torno de trezentas páginas, parecem, a princípio, não estabelecer nexo entre a teoria sociológica e a realidade social. Freqüentemente, apresentava-se tão simplesmente uma lista interminável de conceitos, escolas sociológicas, ramos da sociologia, autores e métodos de pesquisa.

Esta característica 'escolástica' dos manuais de sociologia está bem representada na obra 'Lições de sociologia' de Achiles Archero. Neste manual, que é talvez o mais exemplar representante do enciclopedismo didático que queremos aqui caracterizar, 0 autor nos apresenta nada mais nada menos do que vinte e três definiç̧ões da sociologia ao longo do capítulo dedicado à compreensão da natureza do conhecimento sociológico (ARCHER0, 1935, p. 11).

De modo geral, os autores pareciam ser ainda tributários da tradição livresca que queriam banir. Presos entre conceitos e definições abstratas, descrições de obras e escolas sociológicas, muitas vezes não conseguiam estabelecer relação entre a teoria sociológica e a realidade social brasileira.

É conveniente indagar acerca das razões que explicariam esta dificuldade de corresponder às expectativas originais que os próprios autores eram depositários. Em primeiro lugar, convém lembrar que os autores não tinham formação especializada em sociologia. A rigor, eram eruditos que se empenhavam, não obstante, na formação de um novo perfil de intelectuais. Tarefa para a qual a sociologia foi considerada disciplina fundamental.

Em segundo lugar, podemos deduzir a partir de uma leitura atenta dos textos dos manuais, que havia efetivamente uma ausência de dados acerca da nossa vida social. $\mathrm{Na}$ discussão de temas como alcoolismo ou imigração, por exemplo, os autores apresentavam 
tão simplesmente dados que manifestavam a incidência dos fenômenos nos Estados Unidos ou na Europa. Isto ocorre particularmente entre os manuais publicados nos anos 30. Delgado de Carvalho, que publicou seus livros nesta década, recorre com muita frequiência às estatísticas norte-americanas, malgrado seu desejo expresso de examinar o ponto de vista brasileiro (CARVALHO, 1933).

Entre os manuais publicados na década seguinte, em particular aqueles elaborados por Amaral Fontoura, há maiores dados acerca da realidade brasileira. São comuns, nos seus livros, informações acerca da entrada de imigrantes no Brasil, da renda dos habitantes e dos crimes cometidos no Distrito Federal. A maior apresentação de dados estatísticos em seus livros pode estar relacionada ao trabalho do Instituto Brasileiro de Geografia e Estatística, fundado em 1938 no Rio de Janeiro, responsável pela organização e centralização dos dados antes difusos entre os órgãos estaduais.

Nos anos 30, com efeito, era comum os autores lamentarem esta falta de recursos documentais e bibliográficos sobre a realidade brasileira. Nelson Omegna trata deste problema no prefácio de seu manual:

Para este trabalho muito nos ressentimos de falta de literatura sobre as questões brasileiras. Por iniciativa dos próprios alunos foram endereçados aos secretários e autoridades dos Estados apelos para que encaminhassem à nossa escola publicações relativas ao movimento demográfico, de assistência e de educação, etc. E dados informativos das realizações sociais do país. Do Estado de Minas Gerais, por intermédio de Mario Casassanta, e da Baía por intermédio do Dr. Bernardino José de Souza, nos foi remetido copioso material sobre a vida daqueles Estados. Essas obras foram a base e o início da pequena biblioteca de sociologia. E para aumento das mesmas os estudantes resolveram organizar uma cooperativa do livro, tendo assim conseguido as obras necessárias para o exercício do nosso primeiro ano de trabalho. (OMEGNA, 1934, p. III).

Como se pode contatar através da citação de Nelson Omegna, além de solicitar dados apelando às autoridades estaduais, os autores procuravam mobilizar os alunos para a fundação de pequenos grupos de interessados na reunião de livros e dados relativos à matéria sociológica.

Era, pois, freqüente o apelo dos autores para que fossem fundados 'laboratórios de sociologia' ou 'museus sociais'. Nestes ambientes, esperava-se reunir e preservar documentos, livros, imagens e dados estatísticos sobre problemas sociais do universo em especial do Brasil. Vejamos aqui a definição de Amaral Fontoura: 
0 Museu social compreenderá uma pequena biblioteca de ciências sociais, e ainda gráficos, quadros, fotografias, documentação sobre todos os problemas sociais do universo e em especial do Brasil. Os próprios alunos, sob a direção do mestre, se encarregarão de confeccionar aquele material, paulatinamente. [...] Farão também parte do Museu social, os trabalhos dos alunos, suas monografias e teses apresentadas, bem como os resultados dos inquéritos realizados. No fim de algum tempo, organizando-se um índice criterioso desses trabalhos, ter-se-ia nova e interessante fonte de consulta (FONTOURA, 1944, p.17).

Com efeito, Amaral Fontoura chegava mesmo a publicar, entre as páginas dos seus manuais, alguns levantamentos empíricos produzidos pelos próprios alunos. A publicação dos trabalhos e inquéritos dos alunos parecia ser, para Amaral Fontoura, uma das soluções para a ausência de material empírico sobre a realidade social brasileira. ${ }^{18}$

Não obstante, apesar dos esforços para tentar estabelecer um vínculo maior entre realidade e teoria social, os autores com freqüência observavam que os próprios conteúdos propostos pelos Programas Oficiais de Ensino eram demasiadamente extensos, abrangiam assuntos estranhos à sociologia e dificultavam os nexos da disciplina com a vida social (CARVALHO, 1939). As críticas de Amaral Fontoura nessa direção são mais uma vez exemplares:

Discordamos um pouco desse programa oficial: é por vezes muito prolixo, perde-se em questões de importância secundária, desconhece muitos dos trabalhos modernos atinentes à matéria. [...] Salvo exceções, faz-se ainda, entre nós, um ensino de sociologia morta. Decoram-se definições. Fica-se no terreno estéril das digressões sobre escolas, sobre teorias sobre orientações metodológicas... 0 estudo dos problemas vivos, a discussão palpitante sobre os problemas sociais são inteiramente abandonados! Chegamos ao seguinte cúmulo: discutem-se problemas sociais por toda a parte menos... na aula de sociologia. (FONTOURA, 1944, p. 15-18).

A defasagem entre a expectativa em relação ao ensino da disciplina e os programas de curso era assumida pelos seus próprios autores. Por vezes, o próprio livro didático aparece como um elemento problemático para o ensino da disciplina.

Carneiro Leão éo mais enfático nesta constatação: afirma queé necessário 'libertar o aluno da tirania do compêndio' (CARNEIRO LEÃO, 1940, p. 4). A tirania do compêndio a que se refere parece ser a tradição livresca, herança do bacharelismo jurídico. As obras didáticas são consideradas representantes de uma tradição intelectual que se

\footnotetext{
${ }^{18}$ Entre os trabalhos produzidos pelos alunos e publicados por Amaral Fontoura na $4^{\mathrm{a}}$ edição de Programa de Sociologia encontramos o de Luiz Aguiar da Costa Pinto, realizado quando este freqüentava o curso complementar. Trata-se de um trabalho acerca da organização econômica do Brasil. (FONTOURA, 1944).
} 
queria evitar. Para os autores, com efeito, a vida social estava além das páginas de qualquer livro. As seguintes palavras de Amaral Fontoura são também representativas disso:

0 livro de sociologia é importante, é indispensável mesmo, como guia, como roteiro, como resumo. Mas a sociologia não está dentro dos livros e sim da vida [...] (Fontoura, 1944, p. XXII).

Nesse sentido, a fim de evitar a perspectiva livresca no ensino da disciplina, ao final de cada capítulo, os autores sugeriam aos alunos atividades relacionadas ao aprofundamento dos temas tratados em sala de aula. Estas tarefas compreendiam 0 preenchimento de questionários, o levantamento de bibliografia, a organização de seminários e debates e, principalmente, o desenvolvimento de trabalhos de campo.

Podemos aqui apresentar os tipos de questões que foram elaborados pelos autores: a) definição de conceitos, b) coleta e avaliação de dados estatísticos acerca da realidade brasileira, c) confronto das perspectivas teóricas a partir de estudos de comunidade, d) visitas, trabalhos de campo e aplicação de inquéritos sociais nos bairros de imigrantes e operários e hospitais de caridade.

Com efeito, a maioria das questões elaboradas exigiam de fato mais do que simplória memorização dos conteúdo apresentado. Por isso, podemos dizer com tranqüilidade que os autores procuraram, a despeito de seus limites, favorecer o que chamavam genericamente de 'estudos sociais'. Lançaram, nesse sentido, mão de um dos únicos recursos de que dispunham: a prescrição, malgrado limitada, de atividades de coleta de dados e investigação social.

Mas que tipo de contato com a realidade se pretendia proporcionar aos alunos? Tomaremos mais uma vez como exemplar uma das propostas elaboradas por Amaral Fontoura. Este autor, ao final de um capítulo do livro Programa de sociologia, no qual discutia o que chamou de princípios fundamentais do convívio humano, propôs que os alunos se organizassem em grupos a fim de realizar visitas a albergues, asilos, hospitais, favelas e penitenciárias. Para o desenvolvimento da pesquisa, fez as seguintes recomendações:

Em cada visita procurar conhecer a realidade do problema, ouvindo os interessados diretos, asilados ou trabalhadores. Procurar integrar-se no meio que visita para poder sentir, para viver aquela situação. Tomar numerosas notas, se possível acompanhadas com fotografias. Escrever depois um relatório a respeito. 0 relatório não precisa ser longo. Mas deve compreender nitidamente duas partes: na primeira, 
o estudante expõe tudo o que viu. Na segunda parte, ciritica os fatos, interpreta-os, faz seus julgamentos, enumera as providências que, na sua opinião, deveriam ser tomadas para solucionar ou minorar as dificuldades. (FONTOURA, 1944, p. 167).

Observemos que os alunos deveriam proceder como 'cientistas sociais' : entrevistas, notas, imagens e relatórios conferiam cientificidades às investigações. Manifestariam também solidariedade e brasilidade ao misturar-se e integrar-se aos velhos, doentes, detentos, crianças, trabalhadores e negros marginalizados. Estariam, por um lado, exorcizando o complexo histórico em relação à dificuldade de enfrentar o campo de nossas realidades sociais. Por outro, solidarizavam-se e manifestam esta solidariedade enumerando soluções pontuais para os problemas diagnosticados. Esperava-se, a um só tempo, que a pesquisa sociológica disciplinasse para a vida coletiva, exorcizasse antigos complexos, desenvolvesse vínculos de solidariedade e desenvolvesse certa sensibilidade para a solução dos problemas sociais brasileiros.

Assim, embora nossos autores, não tivessem condições de estabelecer sistematicamente a relação entre a realidade social e as idéias sociológicas, queriam, não obstante criá-las para seus alunos, ou, no mínimo, estimulá-los para o desenvolvimento de condições menos adversas para a pesquisa sociológica.

Na verdade, como demonstram nossos primeiros manuais de sociologia, os desafios para a institucionalização da ciência sociológica eram então imensos: era necessário exorcizar o diletantismo, fundar uma nova perspectiva acerca do trabalho intelectual, ocupar-se com a reunião e o tratamento de dados, com a estruturação de laboratórios, museus e bibliotecas, com a formação de pesquisadores.

Os manuais são, portanto reveladores de um dos dramas mais cruciais para a constituição do campo de estudos sociológicos entre nós: o incentivo à pesquisa num meio em que faltava tradição científica. Sabe-se pois que estes dramas e seus desafios foram enfrentados por personagens que tomaram o ensino e a rotinização da sociologia como uma missão, especialmente no ambiente escolar brasileiro.

Em termos gerais, estas foram às condições do meio intelectual que, de um lado, beneficiaram a ampla repercussão da sociologia e, de outro, ofereceram limites para 0 seu pleno desenvolvimento. Asociologia apareceu como disciplina escolar num momento em que se queria reconhecer a realidade social e constituir a nação; em que se formava uma nova percepção da sociedade, do conhecimento e do papel dos intelectuais. A rotinização do conhecimento sociológico no meio escolar encerra estas expectativas e, ao mesmo tempo, revela as dificuldades para realizá-las. 


\begin{tabular}{|c|c|l|}
\hline & ANO & MANUAL/ AUTOR \\
\hline 1 & 1900 & Sociologia Criminal, de Paulo Egydio de Oliveira Carvalho. \\
2 & 1906 & Estudos de sociologia criminal, de Luciano Pereira da Silva. \\
3 & 1906 & Sociologia criminal: estudos, de J. Mendes Martins. \\
4 & 1926 & Introdução à sociologia geral, de Pontes de Miranda. \\
5 & 1928 & Sociologia Applicada, de Numa P. do Valle. \\
6 & 1931 & Iniciação à sociologia, de Alceu Amoroso Lima. \\
7 & 1931 & Sociologia, de Delgado de Carvalho. \\
8 & 1933 & Lições de sociologia, de Achiles Archero Junior. \\
9 & 1933 & Sociologia Geral, de Rodrigues de Meréje. \\
10 & 1933 & Ensaio de sinthese sociológica, de Miranda Reis. \\
11 & 1934 & Sociologia: problemas prévios, de Tito Prates da Fonseca. \\
12 & 1934 & Sociologia experimental, de Delgado de Carvalho. \\
13 & 1934 & Elementos de sociologia, de Nelson Omegna. \\
14 & 1934 & Princípios de sociologia, de Djacyr Menezes. \\
15 & 1935 & O que é sociologia, de Rodrigues Meréje. \\
16 & 1935 & Noções de sociologia, de Francisca Peeters. \\
17 & 1935 & Sociologia Aplicada, de Delgado de Carvalho \\
18 & 1935 & Princípios de sociologia, de Fernando de Azevedo.. \\
19 & 1938 & Sociologia cristã, de Guilherme Boing. \\
20 & 1938 & Sociologia (outros aspectos da filosofia universal: solução dos problemas \\
21 & 1938 & sociais), de Manuel Carlos. \\
22 & 1938 & Precões de sociologia, de Roberto Lyra. \\
23 & 1939 & Sociologia Política, de Sizínio Leite da Rocha. \\
24 & 1939 & Práticas de sociologia, de Delgado de Carvalho. \\
25 & 1940 & Sociologia Educacional, de Fernando de Azevedo. \\
26 & 1940 & Sociologia Educacional, de Delgado de Carvalho. \\
26 & 1940 & Fundamentos de sociologia, de Carneiro Leão. \\
27 & 1940 & Programa de sociologia, de Amaral Fontoura. \\
28 & 1940 & Um esquema de sociologia geral, de Juvenal Paiva Pereira. \\
\hline & 1941 & Formação da sociologia: introdução histórica às ciências sociais, \\
\hline 2 & 1945 & de Severino Sombra. \\
\hline Introdução à sociologia, Alcionilio Bruzzi Alves da Silva. \\
\hline
\end{tabular}

Quadro 1- Relação dos Manuais de Sociologia Publicados entre 1910 e 1945 


\section{Relação dos Autores}

\section{ACHILLES ARCHÊRO JUNIOR}

Formação e funções ocupadas: Sabemos apenas que o autor foi assistente de Sociologia Educacional do Instituto de Educação da Universidade de São Paulo.

Obras publicadas: "Lições de Sociologia educacional", "Lições de Sociologia", "Dicionário de Sociologia (em co-autoria com Alberto Conte)", "Lições de História da Educaçãa".

ALCEU AMOROSO LIMA (Petrópolis/RJ, 1894 - 1980)

Formação e funções ocupadas: Bacharelou-se em Ciências Jurídicas e Sociais na Faculdade Nacional de Direito, Rio de Janeiro. Fez cursos na Sorbonne e no Collège de France. Atuou como advogado e dirigiu a empresa da família (do ramo têxtil, no Rio de Janeiro). Destacou-se primeiramente no meio intelectual por suas críticas literárias. Após conversão religiosa em 1928, exerceu liderança no movimento de restauração católica ocorrido no Brasil nos anos 30. Dirigiu o Centro D. Vital e a Revista "A Ordem"e foi secretário geral da Liga Eleitoral Católica. Opôs-se à corrente renovadora da educação, especialmente aos representantes da 'Escola Nova'. Em 1937, foi nomeado Reitor da Universidade do Distrito Federal. Dedicou-se também ao magistério. Foi professor de Sociologia e Doutrina Social no Instituto Católico de Estudos Superiores (instituição vinculada ao Centro D. Vital e que precedeu a fundação da Universidade Católica). Lecionou ainda na Faculdade de Serviço Social do Instituto de Educação Familiar e Social do Rio de Janeiro. Ministrou também aulas de Literatura na Universidade do Brasil e na Pontifícia Universidade Católica. A partir da década de 50 assume posições mais liberais e democratas. Em 1964, opôs-se ao Regime Militar. Durante muitos anos escreveu no Jornal do Brasil. Membro da Academia Brasileira de Letras.

Obras publicadas: "A Igreja e o mundo novo", "A Igreja e o povo", "A vida sobrenatural e o mundo moderno", As repercussões do catolicismo", "Bases de uma cristandade", "Contra a revolução espiritual", "De Pio VI a Pio XI", Du régime temporal et la Liberté", "Elementos de ação católica", "Indicações políticas", "João Paulo XXIII", Laphilosophie bergsoniene: études critiques", "Meditação sobre o mundo interior", "Meditação sobre o mundo moderno", "Mensagem de Roma", "No limiar da idade nova", "0 cardeal Leme", "0 desencantamento do mundo: estruturas econômicas e estruturas temporais", "0 existencialismo e outros mitos de nosso tempo", "0 existencialismo", "0 problema do trabalho", "0 trabalho no mundo moderno", "Pela ação católica", "Pela cristianização da idade nova", "Pela reforma social", "Pelo humanismo ameaçado", "Política", "Princípio de uma política humanista", "Problema da burguesia", "Tentativa de itinerário", "Testemunho", "Da tribuna e da imprensa". 


\section{ALCIONÍLIO BRUZZI ALVES DA SILVA (?, ?)}

Formação e funções ocupadas: Tudo leva a crer que era padre salesiano, autor de livros didáticos de diversas disciplinas nos anos 30. Em 1947, compôs a missão civilizadora salesiana entre populações indígenas do Alto Rio Negro e ali passou a maior parte da vida. Obras publicadas: "Introdução à Ciência do Direito", "Lições de físico-química" "Química Geral", "Sobre elementos da filosofia aristotélico-tomista", "Introdução à Sociologia", "A civilização indígena dos uapes",

AFRO DO AMARAL FONTOURA (1912 - ?)

Formação e funções ocupadas: Bacharel pela Faculdade de Filosofia do Brasil, foi professor nas seguintes instituições: Pontifícia Universidade Católica do Rio de Janeiro, Universidade do Estado do Rio de Janeiro, Faculdade de Serviço Social do Distrito Federal, Faculdade de Filosofia Santa Úrsula, Escola do Comando Maior do Exército. Foi presidente da Associação brasileira das Escolas Normais na década de 60.

Obras publicadas: "Programa de sociologia", "Introdução de sociologia", "Sociologia educacional", "Fundamentos da educação", "Metodologia do ensino primário", "Psicologia geral", "O ruralismo: base da economia nacional", "Dicionário Enciclopédico Brasileiro", "0 drama no campo", "Introdução ao serviço social","Aspectos da vida rural brasileira", "Fundamentos da Educação", "Introdução ao Serviço Social", "Psicologia Educacional", "0 planejamento no ensino primário", "Didática especial da primeira série", "Prática de ensino", "Didática geral", "Manual de testes", "Educação cívica e calendário cívico brasileiro"

ANTONIO CARNEIRO LEÃO (Recife/PE, 1887- 1966)

Formação e funções ocupadas: Em 1911, bacharelou-se em Ciências Jurídicas e Sociais pela Faculdade de Direito do Recife. Foi professor de Filosofia em Recife no período compreendido entre os anos de 1910 a 1912. Atuou como jornalista, advogado e professor no Rio de Janeiro de 1916 a 1920. Foi diretor Geral da Instrução Pública do Distrito Federal, de 1922 a 1926. Autor do projeto de Reforma Educacional do Estado de Pernambuco em 1928. Professor chefe do Departamento de Francês do Colégio Pedro II de 1932 a 1937. Professor de Sociologia e Administração Escolar na Escola de Economia e Direito da Universidade do Distrito Federal entre os anos de 1936 e 1937. Diretor do Instituto de Pesquisas Educacionais em 1935. Professor de Administração Escolar e Educação da Universidade do Brasil. Eleito em 1944 para a Academia Brasileira de Letras. Obraspublicadas: "Princípios de sociologia", "Educação", "O Brasil e a educação popular", "A revolução pernambucana de 1817", "Pela educação profissional", "Educação Rural", "O Paraná", "Os problemas da educação", "São Paulo em 1920", "A constituição brasileira e a nossa educação constitucional", "À margem 
da história da República", "Os deveres das novas gerações brasileiras", "Pela conformidade americana", "O ensino capital no Brasil", "Palauras de Fé", "A organização da educação em Pernambuco", "Oproblema do método", "As línguas vivas e uma experiência brasileira", "O ensino das línguas vivas", "Tendências e diretrizes das escolas secundárias", "Introdução da administração escolar", "A sociedade rural, seus problemas, sua educação".

CARLOS DELGADO DE CARVALHO (Paris, 1884- Rio de Janeiro, 1980) Formação e funções ocupadas: Filho de brasileiros, nasceu na França. Formou-se na Escola de Ciências Diplomáticas de Paris e na Escola de Economia e Política de Londres, instituições nas quais teria sido aluno de Durkheim e Hobhouse, respectivamente. No Brasil, na década de 20, foi professor de Geografia, Sociologia e Inglês no Colégio Pedro II. Foi, também, Diretor do Colégio entre 1930 e 1931. Nos anos 30, ministrou aulas no Instituto de Educação do Distrito Federal e na Universidade Federal do Rio de Janeiro, onde lecionou as seguintes disciplinas: Sociologia Educacional, Geografia e História. Foi um dos membros fundadores da Associação Brasileira de Educação e pesquisador do Conselho Regional de Geografia.

Obras publicadas: "Metheorologie du Brésil" "Phisiografia do Brasil" "Geographia do Brasil","Sociologia Educacional", "SociologiaeEducação", "Sociologia experimental", "Sociologia Aplicada", "Sociologia Elementar", "Práticas de sociologia", "Geografia Humana", "Leituras de Sociologia", "Le Brésil Méridional: étude économique sur les états du sud: São Paulo, Paraná, Santa Catarina, Rio de Janeiro", "História diplomática do Brasil", "Organização social e política brasileira", "História Geral", "Relações Internacionais".

DONALD PIERSON (EUA, 1900-1995)

Formação e funções ocupadas: Norte-americano, doutorou-se em Ciências Sociais pela Universidade de Chicago, orientado por Robert Park e apresentando tese acerca dos negros na Babia. Em 1939 veio ao Brasil, onde lecionou as disciplinas de Antropologia e Sociologia na Escola Livre de Sociologia e Política e na Universidade de São Paulo. Em 1941, criou, na Escola Livre de Sociologia e Política, a Divisão de Estudos Pós-Graduados inaugurando o processo de profissionalização dos cientistas sociais no Brasil. Entre os anos de 1950 e 1957 foi editor da primeira revista especializada na área: a Revista Sociologia, criada em 1939.

Obras publicadas: "Pretos e Brancos na Bahia", "Teoria e Pesquisa em Sociologia", "O candomblé na Babia", "Cruz das Almas", "Distribuição espacial das classes e das raças na Babia", "Estudos de Ecologia Humana", "Estudos de 
organização social", "O homem do Vale do São Francisco" (em colaboração com Alceu Maynard de Araújo) .

DJACIR MENEZES (Maranguape-CE, 1907 - 2004)

Formação e funções ocupadas: Iniciou, em 1926, curso de Ciências Jurídicas e Sociais na Faculdade de Direito de Fortaleza, mas transferiu-se para a Faculdade de Direito da Universidade do Brasil, no Rio de Janeiro. Concluiu o bacharelado no ano de 1930. Em 1932, de volta ao Ceará, assumiu as cátedras de Psicologia na Escola Normal Pedro II e de Introdução à Ciência do Direito na Faculdade de Direito do Ceará. Em 1938 fundou, em Fortaleza, a Faculdade de Ciências Econômicas do Ceará, federalizada em 1963 e que hoje compõe a Faculdade de Economia, Administração, Atuária e Contabilidade da Universidade Federal do Ceará. Na década de 60 foi professor da Faculdade de Economia e Administração da Universidade Federal do Rio de Janeiro, onde também ocupou o cargo de reitor.

Obras publicadas: "Diretrizes da educação nacional", "Kant e a idéia de Direito", "Análise científica dos fenômenos históricos", "Evolução do interesse infantil", "A psicologia herbertiana", "Princípios de sociologia", "A teoria científica do direito de Pontes de Miranda", "Análise do conhecimento", "Preparação para o método científico", "Elites agressivas", "Estudos de sociologia e economia", "0 outro Nordeste", "Economia política", "Direito Administrativo", "Finanças de empresas", "0 Brasil no pensamento brasileiro", "Evolução do pensamento literário no Brasil", "Diário de Buenos Aires", "Crítica social de Eça de Queiroz", "Vida social e criação literária".

FERNANDO DE AZEVEDO (São Gonçalo do Sapucaí, MG 1894 - São Paulo, 1974) Formação e funções ocupadas: Bacharel em Ciências Jurídicas pela Faculdade de Direito de São Paulo. Professor de Latim e Psicologia no Ginásio do Estado, em Belo Horizonte. Diretor de Instrução Pública do Distrito Federal entre os anos de 1926 e 1930. Em 1933, assumiu o cargo de Diretor de Instrução Pública de São Paulo. Presidiu a Associação Brasileira de Educação, foi redator e signatário do documento conhecido como 'Manifesto da Escola Nova'. Na década de 30, dirigiu ainda a Companhia Editora Nacional. É considerado um dos fundadores da Universidade de São Paulo. Por muitos anos, escreveu n'0 Estado de São Paulo. Fundou a Sociedade Brasileira de Sociologia. Assumiu a cátedra de Sociologia Educacional na Universidade de São Paulo. Membro da Academia Brasileira de Letras.

Obras publicadas: Da educação física", "Princípios de Sociologia", "Sociologia Educacional", "Da educação física", "No tempo de Petrônio", "Pequena história da literatura", "A educação na encruzilhada", "Canaviais e engenhos na vida política brasileira", "O trem corre para oeste", "As ciências no Brasil", "Novos caminhos e novos 
fins", "A universidade no mundo de amanhã", "A transmissão da cultura", "A educação e seus problemas", "Dicionário de Sociologia", "Aeducação e seus problemas", "Figuras do meu convívio", "História de minha vida", "Na batalha do humanismo".

GILBERTO FREYRE (Recife/PE, 1900-1987)

Formação e funções ocupadas: Formou-se em Ciências Jurídicas e Sociais na Universidade de Baylor, Estados Unidos. Em 1922, pós-graduou-se em Ciências Sociais na Universidade de Colúmbia, Nova Iorque. Foi colaborador e diretor do jornal Diário de Pernambuco. Dirigiu também o jornal A província, no Recife. Em 1924, liderou o Movimento Regionalista do Recife. Entre 1926e 1930, foi chefe de gabinete do governador de Pernambuco Estácio Coimbra. Em 1929, foi nomeado professor de Sociologia da Escola Normal de Pernambuco. Entre os anos de 1935 e 1937 foi professor de Sociologia, Antropologia e Pesquisas Sociais na Universidade do Distrito Federal. Na década de 30, dirigiu a Coleção Documentos Brasileiros da Editora José Olympio. Foi Deputado Federal entre os anos de 1946 a 1950. Em 1949, fundou o Instituto Joaquim Nabuco. Em 1956, foi nomeado por Anísio Teixeira diretor do Centro Regional de Pesquisas Educacionais de Pernambuco. Proferiu conferências em diversas universidades do Brasil e do Exterior.

Obras publicadas: "Casa-Grande \& Senzala", "Sobrados e Mucambos", "Nordeste", "Ordem e Progresso", "Açúcar"Interpretação do Brasil" "Aventura e Rotina", Perfil de Euclides e outros perfis", "Problemas brasileiros de antropologia", "Sociologia: uma introdução aos seus princípios" , "Integração portuguesa nos trópicos", "0 luso e o trópico", "Vida social no Brasil nos meados do século XIX","Quase política", "Brasis, Brasil Brasília", "Como e porque sou e não sou sociólogo", "Rurbanização: o que é", "Homens, Engenharias e rumos sociais", "entre outras.

GUILHERME BOING (?- ?)

Funções ocupadas: Encontramos apenas dois dados acerca das funções desempenhadas por Guilherme Boing: traduziu o livro "AEconomia na Russia" cujo autoréJoão Frederico Normano. E publicou outro livro denominado "Elementos de Economia".

FRANCISCA PEETERS (?- ?)

Formação e funções ocupadas: Madre da Ordem de Santo André. Tudo leva a crer que nasceu na Bélgica e chegou no Brasil em 1914 compondo uma missão de religiosas da ordem para a fundação de uma escola confessional em Jaboticabal, interior de São Paulo.

Obras publicadas: Publicou, além de 'Noções de Sociologia' (1935), o livro 'Pequena história da educação' (1936) em co-autoria com a também Madre Maria Augusta Cooman.. 
FRANCISCO CAVALCANTI PONTES DE MIRANDA (Maceió/AL, 1892 - Rio de Janeiro, 1979)

Formação e funções ocupadas: Em 1911, formou-se em Direito pela Faculdade de Direito do Recife. Foi professor de Direito da Faculdade do Rio de Janeiro e desembargador do Tribunal de Justiça do Distrito Federal. Nos anos 20, fundou a Academia Brasileira de Ciências. Nos anos 40, assumiu a Embaixada brasileira na Colômbia. Membro da Academia Brasileira de Letras.

Obras publicadas: "Anarchismo, communismo, socialismo", "Sistema de ciência positiva do direito", "Introdução à politica científica", "Comentários à Constituição de 1946", "Comentários à Constituição de 1967", "Comentários ao código do processo civil", "Democracia, Liberdade e Igualdade (os três caminhos)", "Dez anos de pareceres", "Fontes e evolução do Direito Civil brasileiro", "História e prática do Habeas Corpus", "Sistema da ciência positiva do Direito", "Os fundamentos atuais do Direito Constitucional", "Tratado da ação rescisória das sentenças e de outras decisões", "Tratado do direito cambiário", "Tratado do direito de família", "Tratado do direito internacional", "Tratado do direito privado", "Tratado dos testamentos".

JOÃO RODRIGUES DE MERÈJE (1902- ?)

Função ocupada: Professor de Sociologia da Escola Normal de Agudos. Traduziu na década de 50, para o português o livro "Crítica da Razão Pura" de Kant.

Obras publicadas: "Apontamentos de química toxicológica", "Apontamentos de Direito constitucional", "Os partidos políticos", "Ação liberal ou fragmentos de uma campanha pela republicanização da República", "Idéias políticas de Alberto Torres", "Sociologia Geral", "0 problema da raça", "0 estado de necessidade", "Das penas e dos delitos", "Introdução ao estudo da criminologia", "Uma lei da evolução penal" ,Abolicao da servidao penal", "Principios de criminologia".

JUVENAL PAIVA PEREIRA (Itapetininga/SP, 1898- ?)

Formação e Funções ocupadas: Formado em Magistério pela Escola Normal de Itapetininga. Em 1925, diplomou-se ainda na Escola de Farmácia e Odontologia da mesma cidade. Em 1937, aprovado em concurso, é nomeado professor de Sociologia da Escola Normal de Itapetininga. Dirigiu a Escola Normal. Foi vereador da cidade.

Obras publicadas: "Um esquema de Sociologia Geral".

NUMA DO VALLE (? - ?)

Obras publicadas: "Da prescrição extinctiva no Direito Civil e Commercial", "Da responsabilidade do Estado", "Familia no Direito Internacional Privado", "Sociologia Applicada". 
NELSON OMEGNA (Niterói, 1903 - 1987)

Formação e funções ocupadas: Formado em Filosofia e Teologia (Faculdade do Rio de Janeiro?). Em Campinas, foi vereador eprofessor de Sociologia do Instituto de Educação e da Faculdade de Filosofia. Nos anos 40, em Brasília, foi Deputado Federal e Ministro do Trabalho, Indústria e Comércio durante o curto governo de Nereu Ramos (entre novembro de 1955 e janeiro de 1956).

Obras publicadas:" As cruzadas", "A independência do México", "Geografia econômica", "Retrato de D. Quixote", "A cidade colonial", "Remédio para a indústria farmacêutica", "A diabolização dos judeus: presença dos sefardins no Brasil colonial".

PAULO EGYDIO DE OLIVEIRA CARVALHO (1844-1906)

Formação e funções ocupadas: Formado em Ciências Jurídicas, professor de Direito na Faculdade de Direito de São Paulo no início do século XX. Oferecia cursos livres de Sociologia na Faculdade e tornou-se, na passagem do século XIX para o século XX, um dos mais importantes rotinizadores das idéias de Durkheim no Brasil, sobretudo aquelas referidas à natureza social do ato criminoso. Foi Senador pelo Estado de São Paulo na primeira década do séculoXX, formulador de um projeto acerca do sistema penitenciário do Estado.

Obras publicadas: "Estudos de sociologia criminal", "Contribuição para a história philosophica da sociologia", "Do conceito scientifico das leis sociologicas".

PAULO AUGUSTO (pseudônimo de PEDRO A. PINTO) (?-?)

Formação e funções ocupadas: Catedrático de Farmacologia na Faculdade de Medicina do Rio de Janeiro. Estudioso de filologia.

Obras publicadas: "Os Sertões de Euclides da Cunha: vocabulário e notas lexicológicas", "Dicionário de Termos de Medicina", "Dicionário de sinônimos", "Locuções e expressões na réplica de Rui Barbosa", "Fatos da língua", "Nugas e rusgas da linguagem", "Preciso de Sociologia".

ROBERTO DE LYRA TAVARES (Recife/PE, 1902- Rio de Janeiro/RJ, 1982) Formação e funções ocupadas: Formou-se na Faculdade de Ciências Jurídicas e Sociais do Rio de Janeiro no ano de 1920. Atuou na Promotoria Pública, onde chegou ao cargo de Procurador Geral. Escreveu em vários jornais cariocas. Foi Ministro da Educação e Cultura entre os meses de julho e setembro de 1962, durante o governo Goulart. Seu ingresso no ensino superior foi no ano de 1933, quando aprovado em concurso público para livre docente de Direito Penal da Faculdade Nacional de Direito. Lecionou também Criminologia, Direito Penal Comparado e História do Direito. Quando foi fundada a Faculdade de Direito do Rio de Janeiro, nos anos 30, lecionou ali Direito Penal até o ano de 1972, quando aposentou-se. 
Obras publicadas: "Condição Moral e Jurídica do Encarcerado - Estudo do Problema Penitenciário", "Fructos Verdes", "Policiais Criminosos", "Patronatos Agrícolas", "Os Crimes Passionais e a Tolerância da Justiça", "Anomalias Sexuais", "0 Exército por Dentro", "Contravenções Criminais em Geral", "0 Pittoresco e o Sensacional no Congresso Dissolvido - Crítica da Eloqüência Parlamentar", "0 Amor e a Responsabilidade Criminal", "Boletim da Sociedade Brasileira de Criminologia", "Eutanásia", "0 Ministério Público e o Jury"; "Economia e Crime", "Divórcio e Ensino Religioso", "Educação Sexual e Criminalidade","Crimes dos Criminalistas". "Confidências com Çriminosos Passionais", "Pontos de Direito Penal", "0 Ensino do Direito Penal e a Doutrina Contemporânea", "Pobres e Ricos em Direito Penal", "Fundamentos de uma Concepção do Direito Penal", "A Lei Penal e os Animais", "A Mulher Criminosa", "0 Beijo como Atentado ao Pudor", "Noções de Sociologia", "Direito Penal", "Euclides da Cunha e a Sociologia Criminal", "O Direito Penal dos Índios", "Noções de Direito Criminal", "A Obra de Ruy Barbosa em Sociologia e Direito Criminal","Criminologia e Direito", entre outras.

SEVERINO SOMBRA DE ALBUQUERQUE (Maranguape/CE 1907- ?)

Formação e funções ocupadas: Militar, fundou, em 1931, a Legião Cearence do Trabalho, um movimento de natureza corporativista e conservador, apoiado pela Igreja Católica, especialmente pela figura de Hélder Câmara. Participou da Ação Integralista Brasileira (AIB) e era um entusiasta do Estado Novo, colaborador da Revista Cultura e Política. Foi presidente do Partido Trabalhista Nacional e Deputado Federal pelo Ceará. Dirigiu a 'Military Rewiew, revista oficial do Estado Maior do Exército Americano. Foi professor de Sociologia da Escola Militar do Realengo e no curso de candidatos à Escola do Estado Maior do Exército. Fundador e reitor da Universidade Severino Sombra em Vassouras, Rio de Janeiro.

Obras publicadas: "0 ideal legionário", "História Monetária do Brasil Colonial", "Pequeno Esboço da História Monetária do Brasil Colonial", "As duas linhas da nossa evolução política".

SIZÍNIO LEITE DA ROCHA (? - ?)

Funções ocupadas: Foi possível apenas constatar que foi autor de alguns artigos acerca da exploração de minério no Oeste do Brasil.

TITO PRATES DA FONSECA (?- ?)

Funções ocupadas: Sabemos apenas que se formou em Ciências Econômicas no ano de 1934 em São Paulo. Possivelmente fizera antes algum curso de Direito, já que se dedicou a publicação de alguns manuais na área jurídica. 
Obras publicadas: "Sociologia: problemas prévios", "Direito Administrativo", "Sucessão Testamentária".

\section{MIRANDA REIS (?- ?)}

Formação e funções ocupadas: Não conseguimos nenhum dado relevante acerca deste autor. Sabemos apenas que foi professor de Sociologia da Universidade do Distrito Federal em 1938 e que ali acompanhou as atividades do Club de Sociologia, fundado por Gilberto Freyre. Foi possível também verificar que este autor traduziu para o português a obra "Sem olhos em Gaza" de Aldous Huxley e "A condição do homem: uma análise dos propósitos e fins do desenvolvimento humano" de Mumford Lewis.

\section{REFERÊNCIAS}

ALMEIDA, Maria Hermínia Tavares de. A institucionalização das Ciências Sociais no Rio de Janeiro. In: MICELI, Sérgio. História das Ciências Sociais no Brasil. São Paulo: Edições Vértice: 1989.

ALONSO,Ângela. De positivismo e de positivistas. Revista Brasileira de Informação Bibliográfica em Ciências Sociais, Rio de Janeiro, n. 42, 2 sem. 1996.

ALVAREZ, Marcos César. Paulo Egidio e a Sociologia Criminal em São Paulo. Tempo Social, São Paulo, v. 12, n. 1, 2000.

AMOROSO LIMA, Alceu. Preparação à sociologia. Rio de Janeiro: D. Vital, 1931.

ARCHERO JR., Achiles. Lições de sociologia. 2. ed. São Paulo: Ed. Pub. Brasil, 1935.

AZEVEDO, Fernando. Princípios de sociologia. 3.ed. São Paulo: Nacional, 1939.

BARBOSA, Rosângela Nair de Carvalho. O projeto da UDF e a formação dos intelectuais. Dissertação de Mestrado, IFCS, UFRJ, 1996.

BEGA, Maria Tarcisa Silva. Gênese das Ciências Sociais no Paraná. In: OLIVEIRA, Márcio (Org.). As Ciências Sociais no Paraná. Curitiba: Protexto, 2006.

BOING, Guilherme. Sociologia cristã. Petrópolis: Vozes, 1938.

CANDIDO, Antonio. Sociologia, ensino, estudo. Sociologia, n. 3, v. 11, p. 275-289, 1949.

CARDOSO, Irene. A universidade da comunbão Paulista. São Paulo: Cortez Editores Associados, 1982.

CARLOS, Manuel. Sociologia outros aspectos da filosofia universal: solução dos problemas sociais). Rio de Janeiro: A. Leite, 1938.

CARNEIRO LEÃO, Antonio. Fundamentos de sociologia. Rio de Janeiro: Jornal do Comercio, 1940 . 
CARVALHO, Carlos Delgado. Práticas de sociologia. Porto Alegre: Globo, 1939.

CARVALHO, Delgado de. Geographia do Brasil. Rio de Janeiro: Impressões Artísticas, 1913.

CARVALHO, Delgado de. Sociologia. 2. ed. Rio de Janeiro: Francisco Alves, 1933.

CARVALHO, Delgado de. Sociologia experimental. Rio de Janeiro: Sauer, 1934.

CARVALHO, Delgado de. Sociologia educacional. São Paulo: Nacional, 1940.

COSTA PINTO, Luis. Ensino da sociologia nas escolas secundárias. Sociologia, n. 3, v. 11, p. 291-308, set. 1949.

EUFRÁSIO, Mario A. Estrutura urbana e ecologia humana: a escola sociológica de Chicago (1915-1940). São Paulo: Universidade de São Paulo, 1999.

FERNANDES, Florestan. 0 ensino da Sociologia na escola secundária brasileira. In: CONGRESSO BRASILEIRO DE SOCIOLOGIA, 1., São Paulo, 1955. Anais ...São Paulo, 1955.

FONSECA, Tito Prates. Sociologia: problemas prévios. São Paulo: Saraiva, 1934.

FONTOURA, Afro do Amaral. Programa de sociologia. Porto Alegre: Globo, 1944.

FONTOURA, Afro do Amaral. Introdução à sociologia. 2. ed. Rio de Janeiro: Aurora, 1953.

FRESTON, Paul. Um império na província: o Instituto Joaquim Nabuco em Recife. In: MICELI, Sérgio. História das Ciências Sociais no Brasil. São Paulo: Vértice, 1989. v. 1.

LIMONGI, Fernando. Revista Sociologia: a ELSP e o desenvolvimento da Sociologia em São Paulo. In: Textos IDESP. Série História das Ciências Sociais, n.1, 1987.

LIMONGI, Fernando. A Escola Livre de Sociologia e Política de São Paulo. In: MICELI, Sérgio. História das Ciências Sociais no Brasil. São Paulo: Edições Vértice, 1989.

MENEZES, Djacir. Princípios de sociologia. Porto Alegre: Globo, 1934.

MERÈJE, Rodrigues de. Sociologia geral. São Paulo: Editorial Paulista, 1933.

MEUCCI, Simone. A experiência docente de Gilberto Freyre na Escola Normal de Pernambuco (1929-1930). Cadernos CRH, Salvador, v. 18, n. 44, 2005.

MEUCCI, Simone. Gilberto Freyre e a Sociologia no Brasil: da sistematização à constituição do campo científico. Tese (Doutorado em Ciências Sociais) - IFCH, Unicamp, 2006.

MICELI, Sérgio. Condicionantes do desenvolvimento das Ciências Sociais. In: MICELI, Sérgio

(Org.). História das Ciências Sociais no Brasil. São Paulo: Vértice, 1989. v. 1.

MORAES, Amaury César. Licenciatura em ciências sociais e ensino de sociologia. Tempo Social, São Paulo, v. 15, 2003.

OMEGNA, Nelson. Geographia Economica. São Paulo: Escolas Profissionais do Liceu Coração de Jesus, 1931.

OMEGNA, Nelson. Elementos de sociologia. Campinas: Liv. João Amêndola, 1934.

PALLARES-BURKE, Maria Lucia Garcia. Gilberto Freyre: um vitoriano nos trópicos. São Paulo: Unesp, 2005. 
PEETERS, Francisca. Noções de sociologia. 2. ed. São Paulo: Melhoramentos, 1938.

PEREZ, Cilmara Ferrari. A formação sociológica das normalistas nas décadas de 20 e 30. Dissertação (Mestrado) - Faculdade de Educação, Unicamp, 2002.

PONTES, Heloísa. Retratos do Brasil: editores, editoras e 'coleções brasiliana' nas décadas de 30, 40 e 50. In: MICELI, Sérgio. (Org.). História das ciências sociais no Brasil. São Paulo: Edições Vértice, 1989. v. 1.

PONTES, Heloísa. Entrevista com Antonio Candido. Revista Brasileira de Ciências Sociais, v. 17, n. $47,2001$.

REIS, V. Miranda. Ensaio de sinthese sociologia. 2. ed. Rio de Janeiro: Ariel, 1935.

SALEM, Tânia. Do Centro D. Vital à Universidade Católica. In: SCHWARTZMAN, Simon. Universidades e Instituições Científicas no Rio de Janeiro. Rio de Janeiro: CNPq, 1982.

SELLAR0, Leda Rejane Accioly. Educação e modernidade em Pernambuco: inovações no ensino público (1920-1937). Tese (Doutorado em História) - Departamento de História da Universidade Federal de Pernambuco, 2000.

SOMBRA, Severino. Formação da sociologia: introdução histórica às ciências sociais. Rio de Janeiro: Livraria José Olympio, 1941.

SORÁ, Gustavo. Brasilianas: a Casa José Olympio e a instituição do livro nacional. Tese (Doutorado em Antropologia Social) - Museu Nacional, UFRJ, 1998.

TOMAZI, Nelson. Considerações preliminares sobre a institucionalização da Sociologia no Paraná. In: OLIVEIRA, Márcio (Org.) As Ciências Sociais no Paraná. Curitiba: Protexto, 2006.

VECHIA, Ariclê; LORENZ, Karl Michael (Org.) Programa de ensino da Escola Secundária Brasileira (1850-1951). Curitiba: Editora do Autor, 1998.

VIANNA, Werneck. Institucionalização das Ciências Sociais e a reforma social: do pensamento social à agenda americana de pesquisa. In: . A revolução passiva; iberismo e americanismo no Brasil. Rio de Janeiro: Revan, 1997.

VICENZI, Lectícia de. A fundação da Universidade do Distrito Federal e seu significado para a educação no Brasil. Fórum Educacional, Rio de Janeiro, v. 10, n. 3, 1986.

VILA NOVA, Sebastião. Donald Pierson e a Escola de Chicago: entre humanistas e messiânicos. Lisboa: Vega Universidade, 1998.

VILA NOVA, Sebastião. Donald Pierson e a Escola de Chicago na Sociologia brasileira: entre humanistas e messiânicos. Lisboa: Vega Gabinete de Edições, 1998.

WEBER, Max. Economia e sociedade. 3. ed. Brasília: Ed. Universidade de Brasília, 1994. 